\title{
Haemophilus haemolyticus, Penicillinase Positive
}

National Cancer Institute

\section{Source}

National Cancer Institute. Haemophilus haemolyticus, Penicillinase Positive. NCI

Thesaurus. Code C123476.

Any bacterial species identified as Haemophilus haemolyticus that produces the enzyme penicillinase. 